\title{
Light quality in vitro growth and acclimatization of two varieties of Phalaenopsis amabilis alba Blume (Orchidaceae)
}

\author{
Raquel Massaro', Dauri Aparecido Fadin', Cristiano Pedroso-de-Moraes², \\ Antônio Sanches Vieira' \& Marco Aurélio Marteline'
}

\author{
1 Universidade Federal de São Carlos. Rodovia Washington Luís, km 235 - SP 310 - Jardim Guanabara, CEP 13565-905, \\ São Carlos, São Paulo, Brasil. \\ ${ }^{2}$ Centro Universitário da Fundação Educacional Guaxupé. Av. Dona Floriana, 463, Centro, CEP 37800-000 Guaxupé, \\ Minas Gerais, Brasil. cpmoraes@gmail.com
}

\begin{abstract}
This study aimed to analyze the in vitro growth and acclimatization of two cultivars (cv. 6323 and cv. 6546) of the species under different light quality regimes. To evaluate the influence of light quality on the growth of seedlings of the two cultivars, plants were submitted to five different light treatments: white, blue, yellow, green and red obtained by wrapping vials with colored cellophane sheets. After 60 days of cultivation, the multivariate statistical evaluation of the results was performed. From the biometric data analysis, it could be seen that the in vitro and ex vitro growth of $P$. amabilis were influenced by different light qualities and the resulting variation occurs due to the influence of the genotype. The blue spectrum exerted a greater influence on the cv. 6323 and the green spectrum on the cv. 6546.
\end{abstract}

Keywords: light quality, micropropagation, orchid

RESUMO - Qualidade de luz no crescimento in vitro e aclimatização de duas variedades de Phalaenopsis amabilis Blume (Orchidaceae). Este estudo teve como objetivo analisar o crescimento in vitro e aclimatização de duas cultivares (cv. 6323 e cv. 6546) da espécie em diferentes qualidades de luz. Para avaliar a influência da qualidade da luz no crescimento de mudas de duas cultivares, plantas foram submetidas a diferentes tratamentos de luz: branca, azul, amarela, verde e vermelha, obtidas por envolvimento dos frascos com folhas de celofane colorido. Após 60 dias de cultivo, foi realizada a avaliação estatística multivariada dos resultados. A partir da análise dos dados biométricos pode ser observado que o crescimento in vitro e ex vitro de $P$. amabilis foram influenciados por diferentes qualidades de luz e a variação resultante ocorre devido à influência do genótipo. Pode ser observado que o espectro azul exerceu maior influência sobre a CV. 6323 e o espectro verde para a cv. 6546.

Palavras-chave: qualidade de luz, micropropagação, orquídea

\section{INTRODUCTION}

Among the main oriental orchids that suffered an intense extraction is the genus Phalaenopsis, which comprises almost 60 described species (Harper 2004). Such plants had their origin in the north of Australia, southeast of Asia, Himalayan mountains, Indonesia and Philippines (Sheehan \& Sheehan 1994). They are characterized for the epiphytic monopodial growth habit and the presence of alternating leaves that are positioned on axillary buds. It is a genus with high ornamental potential and trade in the international market, because belongs to one of few families with representatives showing flowering twice a year (Harper 2004). The correct management of floral rachis (Pedroso-de-Moraes 2000) confers durability to inflorescence for up to three months (Harper 2004).

Such plants had their production widely increased worldwide in the last decades due to both evolution of the production techniques and the interest of the consumers (Wang \& Lee 1994, Griesbach 1995). Thus, with the growth of the international floriculture market, a greater demand occurred for seedling production, requiring more research involving propagation techniques, acclimatization, development of containers, substrates and improvement of practices of orchid culture (Ferreira et al. 2007, Rocha et al. 2009).

The growing demand for plants and orchid flowers has forced producers to buy seedlings from specialized laboratories, which tend to lower their production costs. The investment in material, infrastructure and trained staff require that these laboratories minimize losses and maximize the use of the factors involved in the production (Stancato et al. 2001). Furthermore, with the assistance of in vitro culture it is possible for a plant with desirable interests to be multiplied by several subcultives, leading to a possibility that a new cultivate can be available faster for commercial use (Pasqual 2000), decreasing the indiscriminate harvesting of plant material from wild areas species (Pedroso-de-Moraes 2000). In this way, in vitro propagation has been applied routinely to the orchids of the genus Phalaenopsis. It represents one of most viable forms to propagate plants free from viruses due to the high 
phytosanitary quality of produced plants, in short time, regardless of time of the year and with the possibility of keeping the genetic identity of individuals (Guerra et al. 1999, Pereira \& Fortes 2003).

A factor that has been gaining attention in the production of ornamental plants is the quality of light, since this directly affects the development and the growth of cultivated plants in vitro or ex vitro (Taiz \& Zeiger 2004, Raven et al. 2007, Kerbauy 2012). Several characteristic pigments trigger various responses in plants, like elongation of organs, changes in fitormone concentrations and in anatomical characters, expansion of the photosynthetic apparatus with accumulation of carbohydrates mainly in the leaves, and inhibition or stimulus of axillary buds (Dignart et al. 2009, Kerbauy 2012). However, few investigations have been conducted to compare and understand the effects of different light qualities on the growth and development of in vitro plant tissue growing. Some studies have shown that blue light can influence the hormonal balance in tissues, and that red light increase biomass of seedlings (Erig \& Schuch 2005), justifying the need of research related to the understanding of the influence of light quality on growth and development in vitro and ex vitro of orchid.

Thus, this paper aimed to evaluate the influence of different light qualities on in vitro and ex vitro growth of cultivars named "6323" and "6546" of Phalaenopsis amabilis alba.

\section{MATERIAL AND METHODS}

\section{Plant material}

The study was developed in the in vitro Orchid Propagation Laboratory of the Orchid Nursery Santa Cruz, in the city of Santa Cruz do Rio Pardo, SP, Brazil, $480 \mathrm{~m}$ altitude, $22^{\circ} 54^{\prime} 44,20^{\prime \prime} \mathrm{S}$ latitude and $49^{\circ} 37^{\prime} 28,97^{\prime \prime} \mathrm{O}$ longitude.

To perform the experiment, five flowers of different matrices of Phal. amabilis cultivar Suzuki Santa Cruz alba 038AA were pollinated with whole bulk grain of pollen of Phal. amabilis Suzuki Santa Cruz alba 06AA, receiving the cultivar code: 6323 . Another crossing also was carried out between species Phal. amabilis cultivar Suzuki Santa Cruz alba 097AM and Phal. amabilis cultivar Suzuki Santa Cruz alba 099AA, receiving the code 6546. Six months after the artificial pollination, seeds were selected from mature fruits, which were taken to the Laboratory for the beginning of the germination experiment.

\section{In vitro culture}

The MS growth medium (Murashige \& Skoog 1962), was prepared, and supplemented with $1 \mathrm{~g} . \mathrm{L}^{-1}$ of active charcoal, $30 \mathrm{~g} . \mathrm{L}^{-1}$ of sucrose with $\mathrm{pH}$ adjusted to 5,4 before adding of 7 g.L.- banana-agar broth (Massaro et al. 2012). Next, $25 \mathrm{~mL}$ of growth environment was poured into 250 $\mathrm{mL}$ bottles and autoclaved at $121^{\circ} \mathrm{C}$ at $1 \mathrm{~atm}$ during 20 minutes (Arditti \& Ernest 1992).

Seeds were disinfected by agitation in eppendorf $f^{\circledR}$ microcentrifug tubes with a hypochlorite sodium solution at $5 \%$ during 5 minutes. Next, tubes containing seeds of the two cultivars were dipped in $70 \%$ ethanol during 5 minutes and $t$ washed four times in sterilized distilled water with the assistance of a $1 \mathrm{~mL}$ syringe. Seeds were deposited in bottles containing the MS growth environment (Arditti $\&$ Ernest 1992). The seeded bottles were closed with a transparent plastic cover and maintained during 180 days in a growth room, at $25 \pm 1{ }^{\circ} \mathrm{C}$ temperature, under 12 hours photoperiod and light intensity of about $35 \mu \mathrm{mol} . \mathrm{m}^{-2} \cdot \mathrm{s}^{-1}$.

After 180 days of cultivation, the germinated seedlings were submitted to sub cultivation, a necessary procedure to ensure a greater biometric uniformity in the bottles. This procedure was performed in new bottles containing the MS growth environment (25 plants per bottle). Each one of the bottles of both cultivars utilized for the experiment of luminous quality presented seedlings approximately $4,0 \pm 0,2 \mathrm{~cm}$ of high.

For the evaluation of spectral influence the growth of the seedlings, it was selected 20 bottles ( 10 for each cultivar). Plants were submitted to different light quality: white, blue $(465 \mathrm{~nm})$, yellow $(485 \mathrm{~nm})$, green $(510 \mathrm{~nm})$ and red $(700$ $\left.\mathrm{nm}-0,055 \mu \mathrm{mol} \cdot \mathrm{m}^{-2} \cdot \mathrm{s}^{-1}\right)$, obtained by the utilization of two cellophane paper sheets involving the cultivation bottles (Araújo et al. 2009), in the same conditions of cultivation. The transmittance of the cellophane papers was determined by spectrophotometer Beckman model DU65, between the wavelengths 400 and $800 \mathrm{~nm}, 40 \mathrm{~nm}$ intervals (Almeida \& Mundstock 2001).

After 60 days of cultivation, the seedlings were harvested bottles, washed and submitted to multivariable treatments, under 2 X 5 factorial (two cultivars X five treatments).

\section{Acclimatization}

After biometrics measures, seedlings were bottled in black plastic containers ( $1 \mathrm{~L})$. As a drain, it was utilized expanded clay pebbles were surface-sterilized with calcium hypochlorite at $0,5 \%$ for 30 minutes followed by three washes in running water, with the objective of avoiding the dissemination of pathogens in the growth environment (Pedroso-de-Moraes 2000).

For planting in vases it was previously mounted a sphagnum base in the bottom e all around the recipient. Plants were accommodated in parallel lines with sphagnum in the middle of them until the total fulfill of the vase. All the vases were allocated in countertops at $1,5 \mathrm{~m}$ from the soil with a spacing of $5 \mathrm{~cm}$ between then, procedure that ensures large light exposure to the individuals (Endsfeldz 1998), and maintained in a greenhouse (mesh type sombrite $70 \%$ ) of the Orchid Nursery Santa Cruz, in a mean monthly temperature of $28 \pm 2^{\circ} \mathrm{C}$, air relative humidity of $75 \%$ and luminous intensity of about $800 \mu \mathrm{mol} \cdot \mathrm{m}^{-2} \cdot \mathrm{s}^{-1}$ (Moraes \& Almeida 2004). During all the experimental period the seedlings were fertilized with $2 \mathrm{mg} . \mathrm{L}^{-1}$ Peters ${ }^{\circledR}$ fertilizer NPK 10-10-10 in alternated days, having as criteria for the final irrigation the dryness of the substratum (Pedroso-deMoraes 2000). This experiment, as well as the germination, 
was carried out in a factorial scheme 2 X 5 (two varieties $\mathrm{X}$ five treatments).

\section{Statistics Avaliations}

After two months of growth under several light qualities, the seedlings of the two cultivars of Phal. amabilis alba were submitted to the following biometric evaluation related to growth: Total Seedling Length (TSL), Length of the Air Part (LAP), Dry Mass of the Whole Plant (DMWP), Length of the Larger Leaf (LLL), Number of Roots (NR) and Number of Leaves (NL).

After three months of acclimatization of the seedlings, new biometrics measures were taken, with the objective to verify the influence of several luminous spectra. The variables were analyzed in this experiment were: Seedling Total Length (STL), Length of the Air Part (LAP), Dry Mass of the Whole Plant (DMWP), Dry Mass of the Whole Seedling (DMWS), Length of the Larger Root (LLR), Length of the Larger Leaf (LLL), Number of Roots (NR) and Number of Leaves (NL).

All the measurements were made using a digital caliper rule (Digimess 100A) and an analytical balance (Gehaka BG 400). All data were analyzed by multivariable statistics with the utilization of the application BioEstat 5.3 (Ayres et al. 2007).

\section{RESULTS AND DISCUSSION}

\section{Luminous quality in cultivars in vitro growth}

After the statistical analysis carried out for in vitro growth of seedlings of two $P$. amabilis alba cultivars, it was observed that the mean high values were found for the NR variable in the cultivar 6546 for all the spectra, in detriment of 6323. Moreover, the analysis carried out for each genotype shows greater influence of the yellow light on the length the radicular genesis (NR and LLR) of the cultivar 6323 and of the green over cultivar 6546 (Table 1 and 4). Similar data to LLR for those wavelengths, especially in relation to the influence of the green wavelength, were found for Psidium cattlevanum sabine that was submitted to different light qualities and culture environment formulations for multiplication and in vitro rooting (Klein 1992).

The analysis referent to the number of leaves variable shows no statistic difference for the two cultivars submitted to white light (control). Nonetheless for other light spectra, in all cases, the mean results obtained show higher values for the cultivar 6323 . Yet, the means also did not show statistic difference across spectrum treatments for the two cultivars (Table 1).

This result is probably originated from the fact that leaves irradiated with white light, normally, absorb more light of the blue and red wavelengths (Salisbury \& Ross 1992). The data obtained for different light qualities are also in agreement with those found in the seedlings of the Azorina vidalii (H. C. Wats Feer), in which it was not verified major differences for this variable (Silva \& Debergh 1997). Nevertheless, higher results for NR were obtained in the seedlings of Cattleya loddigesii Lindl cultivated under blue cellophane paper (Araújo et al. 2009).

Regarding the data achieved for the fresh mass, it was not detected differences between and in the cultivars for each genotype to different light quality (Table 1). The same result was obtained for $C$. loddigesii in others light spectrum (Araújo et al. 2009). This fact is opposite to the results obtained in the in vitro seedlings growth of sugarcane (Saccharum sp.). For sugar cane the white and red light spectra, presents the higher means values for FM to the cultivated plants, principally under the length of the red wave (Mothé et al. 2008). However, other studies that analyzed Lilium sp. cultivated under red and blue LEDs and fluorescents lamps, was obtained higher results in the red and blue light spectra for this variable (Lian et al. 2002).

The data scrutiny obtained for the variable STL, shows that the white light (control) and the blue and red spectra, presents the higher results for the cultivar 6323, meanwhile the yellow and green wavelength showed to be more effective in the cultivar 6546 (Table 2). The spectral statistical analysis in the cultivar 6323 showed the higher results for the blue wave length, while the green and yellow spectra presented higher mean value for the cultivar 6546 (Table 2).

Similar results obtained for the cultivar 6323 were found in investigations carried out with explants of Alternanthera brasiliana Kuntze, which demonstrated greater growth per shoot when submitted to blue and green light (Klein 1992). This can also be observed in shoots of Zantedeschia albomaculata Baill, which presents higher results in the length of the red $(760 \mathrm{~nm})$ and blue $(450 \mathrm{~nm})$ wave (Chang et al. 2003). When compared to the data obtained for the cultivar 6546 with the results showed for Klein (1992), cultivated plants in green light achieved the lowest results due the lowest radiant energy of this spectrum. Thus species of orchid with epiphytical habit, due the root system can play photosynthetic function, requires more radiant energy. However, in studies with Malus communis L., it was obtained higher length and number of shoots cultivated in yellow cellophane (Erig \& Schuch 2004), as found for Phal. amabilis alba cultivar 6546.

The data referent to the variables LLR, LLL, LAP shows that the utilization of the white light generated a higher mean value for the cultivar 6323 when compared to the cultivar 6546 . Still, analyzing the cultivars, it could be observed that all the other luminous spectra presented greater mean values regarding the LLR for the cultivar 6546 . In the cultivar 6323 , the blue wave length was more effective for increasing the LAP of the seedlings and in the LLL (Table 2).

The relation between the LLR and the white light is confirmed by the investigation made with Morus nigra $\mathrm{L}$. in which the white light provided the highest mean values for the LLR, as the results found in this work for the cultivar 
Table 1. Biometric data regarding the number of roots and leaves and fresh mass of seedlings of two cultivars of Phalaenopsis amabilis alba cultured in vitro for 60 days, under different light qualities.

\begin{tabular}{|c|c|c|c|c|c|}
\hline Cultivar & Control & Yellow & Blue & Green & Red \\
\hline \multicolumn{6}{|c|}{ Number of roots } \\
\hline 6323 & $3.6 \mathrm{Be}^{1}$ & 4.7 $\mathrm{Ba}$ & $4.5 \mathrm{Bb}$ & $4.3 \mathrm{Bc}$ & $4.1 \mathrm{Bd}$ \\
\hline 6546 & $5.6 \mathrm{Ab}$ & $5.3 \mathrm{Ac}$ & $5.7 \mathrm{Ab}$ & $5.9 \mathrm{Aa}$ & $5.1 \mathrm{Ad}$ \\
\hline $\mathrm{CV}(\%)$ & 12.97 & 1.75 & 3.69 & 10.65 & 5.71 \\
\hline \multicolumn{6}{|c|}{ Number of leaves } \\
\hline 6323 & $3.0 \mathrm{Ab}$ & $3.5 \mathrm{Aa}$ & $3.5 \mathrm{Aa}$ & $3.4 \mathrm{Aa}$ & $3.6 \mathrm{Aa}$ \\
\hline 6546 & $3.0 \mathrm{Aa}$ & $2.9 \mathrm{Ba}$ & $2.8 \mathrm{Ba}$ & $2.8 \mathrm{Ba}$ & $3.0 \mathrm{Ba}$ \\
\hline $\mathrm{CV}(\%)$ & - & 6.81 & 7.85 & 7.91 & 4.88 \\
\hline \multicolumn{6}{|c|}{ Fresh mass (g) } \\
\hline 6323 & $0.3 \mathrm{Aa}$ & $0.4 \mathrm{Aa}$ & $0.4 \mathrm{Aa}$ & $0.4 \mathrm{Aa}$ & $0.4 \mathrm{Aa}$ \\
\hline 6546 & $0.3 \mathrm{Aa}$ & $0.2 \mathrm{Aa}$ & $0.2 \mathrm{Aa}$ & $0.2 \mathrm{Aa}$ & $0.2 \mathrm{Aa}$ \\
\hline $\mathrm{CV}(\%)$ & - & 6.45 & 6.14 & 6.82 & 9.44 \\
\hline
\end{tabular}

1 Numbers followed by the same capital letter in the same columns and small letters in the same lines, do not differ by Tukey test at $5 \%$ ( $>>0.05$ ).

Table 2. Biometric data regarding the total length of seedling, length of the largest root, length of air part and length of the largest leaf of seedlings of two cultivars of Phalaenopsis amabilis alba cultured in vitro for 60 days, under different light qualities.

\begin{tabular}{|c|c|c|c|c|c|}
\hline Cultivar & Control & Yellow & Blue & Green & Red \\
\hline \multicolumn{6}{|c|}{ Total length of the seedling $(\mathrm{cm})$} \\
\hline 6323 & $6.96 \mathrm{Ab}^{1}$ & $6.36 \mathrm{Bd}$ & 7.66 Aa & $6.35 \mathrm{Bd}$ & $6.63 \mathrm{Ac}$ \\
\hline 6546 & $5.33 \mathrm{Bd}$ & $7.29 \mathrm{Aa}$ & $6.66 \mathrm{Bc}$ & $7.50 \mathrm{Aa}$ & $6.94 \mathrm{Ab}$ \\
\hline $\mathrm{CV}(\%)$ & 8.65 & 5.12 & 4.52 & 2.95 & 5.08 \\
\hline \multicolumn{6}{|c|}{ Length of the largest root $(\mathrm{cm})$} \\
\hline 6323 & $3.96 \mathrm{Aa}$ & $3.50 \mathrm{Bb}$ & $3.22 \mathrm{Bb}$ & $3.29 \mathrm{Bb}$ & $3.53 \mathrm{Bb}$ \\
\hline 6546 & $2.86 \mathrm{Bb}$ & $4.45 \mathrm{Aa}$ & 4.31 Aa & $4.24 \mathrm{Aa}$ & $4.46 \mathrm{Aa}$ \\
\hline $\mathrm{CV}(\%)$ & 8.59 & 5.87 & 3.17 & 3.76 & 4.6 \\
\hline \multicolumn{6}{|c|}{ Length of air part $(\mathrm{cm})$} \\
\hline 6323 & $2.65 \mathrm{Ab}$ & $2.51 \mathrm{Ab}$ & $3.16 \mathrm{Aa}$ & $2.98 \mathrm{Aab}$ & $2.84 \mathrm{Aab}$ \\
\hline 6546 & $1.93 \mathrm{Bc}$ & $2.57 \mathrm{Ab}$ & $2.44 \mathrm{Bb}$ & $2.98 \mathrm{Aa}$ & $2.62 \mathrm{Ab}$ \\
\hline $\mathrm{CV}(\%)$ & 9.34 & 1.71 & 10 & 12.69 & 7.39 \\
\hline \multicolumn{6}{|c|}{ Length of the largest leaf $(\mathrm{cm})$} \\
\hline 6323 & $2.33 \mathrm{Ad}$ & $2.07 \mathrm{Be}$ & $2.81 \mathrm{Aa}$ & $2.62 \mathrm{Ab}$ & $2.46 \mathrm{Ac}$ \\
\hline 6546 & $1.60 \mathrm{Bc}$ & $2.42 \mathrm{Ab}$ & $2.60 \mathrm{Ba}$ & $2.72 \mathrm{Aa}$ & $2.41 \mathrm{Ab}$ \\
\hline CV $(\%)$ & 16.22 & 5.67 & 2.99 & 13.44 & 10.51 \\
\hline
\end{tabular}

\footnotetext{
${ }^{1}$ Numbers followed by the same capital letter in the same columns and small letters in the same lines, do not differ by Tukey test at $5 \%$ (p>0.05).
} 
6323 (Pasa 2012). Yet, the red light presented higher values in the in vitro growth of $C$. loddigesii (Costa et al. 2007).

Regarding to the LLL, opposite to the results obtained in this work, usually, the red light is the one which promotes the higher results for the length of the leaves in several species (Holcman \& Sentelhas 2012).

Following the statistics analysis, the cultivar 6323 did not present significant difference for the LAP across luminous spectra.

The usage of different qualities of light in the in vitro growth of Coffea arabica L., showed the higher results for the LAP in the samples exposed to green and red light. However, it was reported that in the in vitro growth of $C$. loddigesii Lindl. the red cellophane induced the stretching of the LAP (Henrique et al. 2011). Nevertheless, for the cultivar 6546 , higher results were found in cultivated plants under the green spectrum.

It is known, however, that the red wave length normally promotes the stretching of the air part (Silva \& Debergh 1997, Marks \& Simpson 1999), but there are several authors reporting that the influence of the spectral quality regarding the growth and development of seedlings is directly linked to the studied species (Antonopolou et al. 2004, Hunter \&
Burritt 2004), what can explain the different results found in the present study. Regarding the confirmation of these statements is reported that the Orchidaceae Phal. Amabilis present great photosynthetic plasticity when cultivated in several luminous spectra, be this growth in vitro or ex vitro (Lin \& Hun 2004).

\section{Luminous quality in cultivars aclimation}

The biometric analysis carried out in the post phase of the seedlings acclimation of two cultivars of Phal. amabilis alba showed that the highest mean values for the variable NR were obtained in the cultivar 6546 for all the spectra when compared to the cultivar 6323 . However, analyzing each cultivar separately we have that the red spectrum presents higher results for the cultivar 6323 and the white and green spectra the lowest results in the cultivar 6546 (Table 3). This fact confronts the one found in Cattleya loddigesii and C. walkeriana Lindl, for which it was not observed significant differences in the NR under the treatments in the growth rooms, greenhouse and growth house with blue cover (Costa et al. 2007, Dignart et al. 2009).

Table 3. Biometric data regarding the number of roots and leaves and fresh mass of seedlings of two cultivars of Phalaenopsis amabilis alba cultured in vitro for 60 days, under different light qualities.

\begin{tabular}{|c|c|c|c|c|c|}
\hline Cultivar & Control & Yellow & Blue & Green & Red \\
\hline \multicolumn{6}{|c|}{ Number of roots } \\
\hline 6323 & $4.56 \mathrm{Bb}$ & $4.66 \mathrm{Bb}$ & $4.33 \mathrm{Bc}$ & $4.66 \mathrm{Bb}$ & $4.83 \mathrm{Ba}$ \\
\hline 6546 & $5.76 \mathrm{Aa}$ & $5.00 \mathrm{Ab}$ & $5.33 \mathrm{Ac}$ & $5.70 \mathrm{Aa}$ & $5.33 \mathrm{Ab}$ \\
\hline $\mathrm{CV}(\%)$ & 2.43 & 1.62 & 3.03 & 3.25 & 3.48 \\
\hline \multicolumn{6}{|c|}{ Number of leaves } \\
\hline 6323 & $3.56 \mathrm{Ac}$ & $3.86 \mathrm{Ab}$ & $3.96 \mathrm{Aa}$ & $3.63 \mathrm{Bc}$ & $3.96 \mathrm{Aa}$ \\
\hline 6546 & $3.53 \mathrm{Ab}$ & $3.53 \mathrm{Bb}$ & $3.36 \mathrm{Bc}$ & $3.86 \mathrm{Aa}$ & $3.86 \mathrm{Ba}$ \\
\hline $\mathrm{CV}(\%)$ & 1.63 & 6.54 & 1.71 & 1.53 & 1.57 \\
\hline \multicolumn{6}{|c|}{ Fresh mass (g) } \\
\hline 6323 & $1.93 \mathrm{Aa}$ & $1.83 \mathrm{Ab}$ & $1.90 \mathrm{Aa}$ & $1.61 \mathrm{Bd}$ & $1.77 \mathrm{Bc}$ \\
\hline 6546 & $1.93 \mathrm{Ac}$ & $1.89 \mathrm{Ac}$ & $1.93 \mathrm{Ac}$ & $2.44 \mathrm{Aa}$ & $2.09 \mathrm{Ab}$ \\
\hline $\mathrm{CV}(\%)$ & - & 6.05 & 3.48 & 5.08 & 5.68 \\
\hline \multicolumn{6}{|c|}{ Dry mass (g) } \\
\hline 6323 & $0.086 \mathrm{Bc}$ & $0.103 \mathrm{Aa}$ & $0.106 \mathrm{Aa}$ & $0.094 \mathrm{Bb}$ & $0.103 \mathrm{Aa}$ \\
\hline 6546 & $1.946 \mathrm{Aa}$ & $0.110 \mathrm{Ac}$ & $0.100 \mathrm{Ac}$ & $0.130 \mathrm{Ab}$ & $0.116 \mathrm{Ac}$ \\
\hline $\mathrm{CV}(\%)$ & 16.01 & 10.13 & 2.71 & 2.99 & 9.34 \\
\hline
\end{tabular}


Regarding the data found in the variable NL it is observed that the cultivar 6323 presented the higher results under the length of blue and red wave, meanwhile the cultivar 6546 showed the higher results in the green and red wave lengths. It can be found similar results to this work in experiments with Alternanthera brasiliana, which presented a larger NL per explant in the presence of blue light, followed by leaves submitted to the white and green lights (Klein 1992). The same is found in studies with Impatiens walleriana Hook f. and Viola $x$ witrockiana cultivated under blue and red mesh, which presented higher results under blue mesh, however, in experiment with Zantedeschia sp., the red mesh showed higher results to this variable (Chang et al. 2003).

The analysis referent to the biometric data of the FM reveals that the cultivar 6546 presented the higher means for this variable in all luminous spectra in which the seedlings were submitted. Still, analyzing each genotype shows greater influence of the white and length of the blue wave for the cultivar 6323 and of the green for the cultivar 6546.

It is known that the blue wave lengths transmit more energy that the ones in the red spectrum. This affirmation is corroborating by the fact that in Phalaenopsis sp., was observed higher results in growth when seedlings was submitted for blue light. Still, it highlights that some plants maintain their stomata open under blue mesh even in atypical conditions, and that the blue light dilates the guard cells, maintaining the ostiolar open, allowing more $\mathrm{CO}_{2}$ inside the cell, and by doing so, increasing the photosynthetic rate (Taiz \& Zeiger 2004).

The means related to the dry mass of the seedlings reveal that the cultivar 6546 presented the best means for all the wave lengths in comparison to the cultivar 6323. However, analyzing each cultivar we have that the blue spectrum presents the higher results in cultivar 6323 and to the white light for the cultivar 6546 . The results found for the blue wave length corroborate to by the results obtained with Artemisia vulgaris L., which when cultivated under blue and white screen showed the higher results for this variable when compared to others colors of screen tested (Oliveira et al. 2009). However, opposite results were found in the growth of seedlings of $C$. arabica and Ocimum gratissimum $\mathrm{L}$. in which the seedlings cultivated under red mesh presented the higher results (Martins et al. 2008, Henrique et al. 2011).

The statistical analysis of the STL shows that the blue wavelength increased the seedlings length for the cultivar 6323 as the green was for the cultivar 6546 (Table 4). The analysis of Aralia sp., Monstera deliciosa, Aspidistra elatior and Asparagus sp. verify larger vegetative growth under

Table 4. Biometric data regarding the total length of seedling, length of the largest root, length of air part and length of the largest leaf of seedlings of two cultivars of Phalaenopsis amabilis alba cultured in vitro for 60 days, under different light qualities.

\begin{tabular}{|c|c|c|c|c|c|}
\hline Cultivar & Control & Yellow & Blue & Green & Red \\
\hline \multicolumn{6}{|c|}{ Total length of the seedling $(\mathrm{cm})$} \\
\hline 6323 & $7.83 \mathrm{Ab}$ & $6.96 \mathrm{Bd}$ & $8.00 \mathrm{Aa}$ & $7.41 \mathrm{Bc}$ & $7.90 \mathrm{Ab}$ \\
\hline 6546 & $7.03 \mathrm{Be}$ & $7.45 \mathrm{Ac}$ & $7.27 \mathrm{Bd}$ & $8.23 \mathrm{Aa}$ & $7.81 \mathrm{Ab}$ \\
\hline $\mathrm{CV}(\%)$ & 1.56 & 3.74 & 6.48 & 4.90 & 4.31 \\
\hline \multicolumn{6}{|c|}{ Length of the largest root $(\mathrm{cm})$} \\
\hline 6323 & $4.15 \mathrm{Ab}$ & $3.76 \mathrm{Bd}$ & $4.08 \mathrm{Ab}$ & $3.92 \mathrm{Bc}$ & $4.26 \mathrm{Aa}$ \\
\hline 6546 & $3.93 \mathrm{Bc}$ & $4.40 \mathrm{Aa}$ & $3.93 \mathrm{Bc}$ & $4.22 \mathrm{Ab}$ & $4.14 \mathrm{Bb}$ \\
\hline $\mathrm{CV}(\%)$ & 1.43 & 2.25 & 2.51 & 6.82 & 1.32 \\
\hline \multicolumn{6}{|c|}{ Length of air part $(\mathrm{cm})$} \\
\hline 6323 & $3.93 \mathrm{Aa}$ & $3.40 \mathrm{Bc}$ & $3.90 \mathrm{Aa}$ & $3.43 \mathrm{Bc}$ & $3.64 \mathrm{Bb}$ \\
\hline 6546 & $3.36 \mathrm{Bc}$ & $3.68 \mathrm{Ab}$ & $3.38 \mathrm{Bc}$ & $3.77 \mathrm{Aa}$ & $3.74 \mathrm{Aa}$ \\
\hline $\mathrm{CV}(\%)$ & 2.55 & 2.42 & 1.39 & 1.52 & 1.70 \\
\hline \multicolumn{6}{|c|}{ Length of the largest leaf $(\mathrm{cm})$} \\
\hline 6323 & $3.28 \mathrm{Ad}$ & $2.57 \mathrm{Bc}$ & $3.23 \mathrm{Ad}$ & $2.79 \mathrm{Bb}$ & $2.95 \mathrm{Ba}$ \\
\hline 6546 & $2.74 \mathrm{Bc}$ & $2.68 \mathrm{Ad}$ & $2.69 \mathrm{Bd}$ & $3.16 \mathrm{Ab}$ & $3.24 \mathrm{Aa}$ \\
\hline $\mathrm{CV}(\%)$ & 9.69 & 3.91 & 5.79 & 4.19 & 8.54 \\
\hline
\end{tabular}


red mesh, and a retarded under the blue mesh (Shahak et al. 2002). In the experiment with Raphia sp. it wasn't verified the influence of colored mesh in the species growth, supposing that this occurred because that the plants have substances that enables the photosynthesis in a more effective way under blue light frequencies (Meirelles et al. 2007). Besides that, works with $O$. gratissimun shows higher mean values obtained for the cultivated plants under blue colored mesh (Martins et al. 2008). This fact is confirmed in the studies carried out by Souza et al. (2010), in which his plants Mikania glomerata Sprengel and Mikania laevigata Schultz Bip. ex Baker, also presented best means under blue mesh.

Analyzing the biometric LLR data it was noticed higher means on the cultivar 6323 under the red spectrum and on the cultivar 6546 under the yellow spectrum. For $C$. walkeriana it was no significant difference between the spectral quality treatments for this variable (Dignart et al. 2009).

For the length variable of the LAP the white light and the blue wavelengths were the higher for the cultivar 6323, meanwhile the cultivar 6546 presented the higher means in length of the green and red wave. Similar results were found in an investigation with micropropagated $C$. loddigesii, in which there was obtained the higher results for this variable in the growth room with the blue and red mesh (Araujo et al. 2009), in agreement also with the results obtained for $C$. walkeriana, however in in vitro growth (Dignart et al. 2009).

Regarding to the variable LLL the highest results demonstrated that the red luminous spectrum shows the higher results for both cultivars, followed by the green spectrum (Table 4). Similar results were reported in the works with Raphia sp. and C. arabica, in which the red mesh provided best results (Meirelles et al. 2007, Henrique et al. 2011). However, for the plant A. vulgaris, the greater mean values were obtained in cultivated plants under blue mesh, meanwhile in the other treatments there were no differences (Oliveira et al. 2009).

The Phalaenopsis amabilis alba growth, in vitro development and acclimatization phase was influenced by the different qualities of light, being this influence variable across genotypes. Between the two cultivars analyzed, cv. 6323 achieved the higher results in relation to the treatments when compared to cv. 6546 .

Statistical analysis phase in vitro and acclimatization revealed that blue wavelength showed the greatest impact for the cv. 6323 while the green spectrum provided a more effective medium for the cv. 6546 .

\section{REFERENCES}

Almeida, M.L., \& Mundstock, C.M. 2001. A qualidade da luz afeta o afilhamento em plantas de trigo, quando cultivadas sob competição. Ciência Rural 31:401-408.

Antonopoulou, C., Dimassi, K., Therios, I. \& Chatzissavvidis, C. 2004. The influence of radiation quality on the in vitro rooting and nutrient of peach rootstock. Biologia Plantarum 48:549-553.
Araújo, A.G., Pasqual, M., Rodrigues, F.A., Rodrigues, J., Castro, E.M. \& Santos, A.M. 2009. Crescimento in vitro de Cattleya loddigesii Lindl. em diferentes espectros luminosos associados com ácido giberélico. Revista Ceres 56:542-546.

Arditti, J. \& Ernest, R. 1992. Micropropagation of orchids. John Wiley $\&$ Sons, New York. 682 p.

Ayres, M., Ayres Júnior, M., Ayres, D.L. \& Santos, A.A. 2007. BIOESTAT - Aplicações estatísticas nas áreas das ciências biomédicas. Ong Mamiraua, Belém, Pará. 234 p.

Chang, H.S., Charkabarty, D., Hahn, E.J. \& Paek, K.Y. 2003. Micropropagation of Calla lily (Zantedeschia albomaculata) via in vitro shoot proliferation. In Vitro Cellular \& Developmental BiologyPlant 39:129-134.

Costa, A.S, Arrigoni-Blank, M.F., Blank, A.F., Mendonça, A.B., Amancio, V.F. \& Ledo, A.S. 2007. Estabelecimento de alecrim-pimenta in vitro. Revista Horticultura Brasileira 25:68-72.

Dignart, S.L., Castro, E.M., Pasqual, M., Ferronato, A., Braga, F.T.B. \& Paiva, R. 2009. Luz natural e concentrações de sacarose no cultivo in vitro de Cattleya walkeriana. Ciência e Agrotecnologia 33:780-787.

Erig, A.C. \& Schuch, M.W. 2005. Tipo de luz na multiplicação in vitro de framboeseira (Rubus idaeus L.) "Batum". Revista Brasileira de Fruticultura 27:488-490.

Endsfeldz, W.F. 1998. Galeria de espécies. O Mundo das Orquídeas 2: $22-27$

Ferreira, C.A., Paiva, P.D.O., Rodrigues, T.M., Ramos, D.P., Carvalho, J.G. \& Paiva, P. 2007. Desenvolvimento de mudas de bromélia (Neoregelia cruenta (R. Graham) L. B. Smith) cultivadas em diferentes substratos e adubação foliar. Ciência e Agrotecnologia 31:666-671.

Griesbach, R.J. 1995. A Phalaenopsis in every pot. Orchid Digest 59:4243.

Guerra, M.P., Dal Vesco, L.L., Pescador, R., Schuelter, A.R. \& Nodari, R.O. 1999. Estabelecimento de um protocolo regenerativo para a micropropagação do abacaxizeiro. Pesquisa Agropecuária Brasileira 34:1557-1563.

Harper, T. 2004. Phalaenopsis culture: advice for growing 20 species. Orchids Magazine 73:118-127.

Henrique, P.C., Alves, J.D., Deuner, S., Goulart, P.F.P. \& Livramento, D.E. 2011. Aspectos fisiológicos do desenvolvimento de mudas de café cultivadas sob telas de diferentes colorações. Pesquisa Agropecuária Brasileira 46:458-465.

Holcman, E. \& Sentelhas, P.C. 2012. Microclimate under different shading screens in greenhouses cultivated with bromeliads. Revista Brasileira de Engenharia Agrícola e Ambiental 16:858-863.

Hunter, D.C. \& Burritt, D.J. 2004. Light quality influences adventitious shoot production from cotyledon explants of lettuce (Lactuca sativa L.). In Vitro Cellular and Developmental Biology - Plant 40:215-220.

Kerbauy, G.B. 2012. Fisiologia vegetal. Guanabara Koogan, Rio de Janeiro. $478 \mathrm{p}$.

Klein, R.M. 1992. Effects of green light on biological systems. Biological Review 67:199-284.

Lian, M.L., Murthy, H.N. \& Paek, K.Y. 2002. Effects of light emitting diodes (LEDs) on the in vitro induction and growth of bulblets of Lilium oriental hybrid 'Pesaro'. Scientia Horticulturae 94:365-370.

Lin, M. \& Hun, B. 2004. Photosynthetic plasticity of Phalaenopsis in response to different light environments. Journal of Plant Physiology 161:1259-1268.

Marks, T.R. \& Simpson, S.E. 1999. Effect of irradiance on shoot development in vitro. Plant Growth Regulation 28:133-142.

Martins, J.R., Alvarenga, A.A., Castro, E.M., Pinto, J.E.B.P. \& Silva, A.P.O. 2008. Avaliação do crescimento e do teor de óleo essencial em plantas de Ocimum gratissimum L. cultivadas sob malhas coloridas Revista Brasileira de Plantas Medicinais 10:102-107.

Massaro, R., Souza-Leal, T., Cordeiro, G.M. \& Pedroso-de-Moraes, C. 2012. Desenvolvimento in vitro de Epidendrum secundum Jacq. em meios de cultivo simplificados. Revista em Agronegócios e Meio Ambiente 5:337-351.

Meirelles, A.J.A., Paiva, P.D.O., Oliveira, M.I. \& Tavares, T.S. 2007. Influência de diferentes sombreamentos e nutrição foliar no desenvolvimento de mudas de palmeira-ráfia (Rhapis excelsa) (Thunberg) Henry ex. Rehder. Ciência e Agrotecnologia 31:18841887. 
Moraes, C. P. \& Almeida, M. 2004. Influência climática sobre a plasticidade fenotípica floral de Catasetum fimbriatum Lindley. Ciência e Agrotecnologia 28: 942-948

Mothé, G.P.B., Netto, A.T., Crespo, L.E.C. \& Campostrini, E. 2008. Eficiência fotoquímica e características de crescimento da cana-deaçúcar (Saccharum officinarum L.) cultivada in vitro em diferentes concentrações de sacarose e qualidade de luz. Plant Cell Culture \& Micropropagation 4:84-91.

Murashige, T. \& Skoog, F. 1962. A revised medium for rapid growth and bioassays with tobacco tissue cultures. Physiologia Plantarum 15:473-497.

Oliveira, M.I., Castro, E.M., Costa, L.C.B. \& Oliveira, C. 2009. Características biométricas, anatômicas e fisiológicas de Artemisia vulgaris L. cultivada sob telas coloridas. Revista Brasileira de Plantas Medicinais 11:56-62.

Pasa, M., Carvalho, G.L., Schuch, M.W., Schmitz, J.D., Morchelsen, M.M., Nickel, G.K., Sommer, L.R., Lima, T.S. \& Camargo, S.S. 2012. Qualidade de luz e fitorreguladores na multiplicação e enraizamento in vitro da amoreira-preta 'Xavante'. Ciência Rural 42:1392-1396.

Pasqual, M. 2000. Propagação de plantas ornamentais. Universidade Federal de Lavras, Lavras. 80 p.

Pedroso-de-Moraes, C. 2000. Cultivo de orquídeas. Biblioteca Duse Rüegger Ometto, Araras. 130 p.

Pereira, J.E.S. \& Fortes, G.R.L. 2003. Protocolo para a produção de material propagativo de batata em meio líquido. Pesquisa Agropecuária Brasileira 38:1035-1043.

Raven, P.H., Evert, R.F. \& Eichhorn, S.E. 2007. Biologia vegetal. Guanabara Koogan, Rio de Janeiro. 856 p.
Rocha, E.L.J., Carvalho, A.C.P.P. de, Azevedo, B.M. de, Marinho, A.B., Viana, T.V. de A. \& Vasconcelos, D.V. 2009. Aclimatização de mudas micropropagadas de helicônia em ambiente protegido em função do tipo de substrato. Ciência e Agrotecnologia 33:1457-1462.

Salisbury, F.B. \& Ross, C.W. 1992. Plant physiology. Wadsworth Publishing Company, Belmont. 682 p.

Shahak, Y., Gussakovsky, E.E., Gal, E. \& Ganelenin, R. 2002. Growing Aralia and Monstera under colored shade nets. Olam Poreah July Issure 13:60-62.

Sheehan, T. \& Sheehan, M. 1994. An illustrated survey of orchid genera. Timber Press, Portaland. 293 p.

Silva, M.H. \& Debergh, P.C. 1997. The effect of light quality on the morphogenesis of in vitro cultures of Azorina vidalii (Wats.) Feer. Plant Cell, Tissue and Organ Culture 51:187-193.

Souza, G.S., Castro, E.M., Soares, A.M. \& Pinto, J.E.B.P. 2010. Características biométricas e fisiológicas de plantas jovens de Mikania glomerata Sprengel e Mikania laevigata Schultz Bip. ex Baker cultivadas sob malhas coloridas. Revista Brasileira de Biociências 8:330-335.

Stancato, G.C., Bemelmans, P.F.E. \& Vegro, C.L.R. 2001. Produção de mudas de orquídeas a partir de sementes in vitro e sua viabilidade econômica: estudo de caso. Revista Brasileira de Horticultura Ornamental 7:25-33.

Taiz, L. \& Zeiger, E. 2004. Fisiologia Vegetal. Artmed Editora, Porto Alegre. 792 p.

Wang, Y.T. \& Lee, N. 1994. A new look for an old crop: potted blooming orchids. Greenhouse Grower 12:79-80. 